\title{
IRON OXIDATION ON THE SURFACE OF ADVENTITIOUS ROOTS AND ITS RELATION TO AERENCHYMA FORMATION IN RICE GENOTYPES ${ }^{(1)}$
}

\author{
Marquel Jonas Holzschuh ${ }^{(2)}$, Filipe Selau $\operatorname{Carlos}^{(3)}$, Felipe de Campos Carmona ${ }^{(4)}$, \\ Humberto Bohnen ${ }^{(4)}$ \& Ibanor Anghinoni ${ }^{(5)}$
}

\begin{abstract}
SUMMARY
Establishment of the water layer in an irrigated rice crop leads to consumption of free oxygen in the soil which enters in a chemical reduction process mediated by anaerobic microorganisms, changing the crop environment. To maintain optimal growth in an environment without $\mathrm{O}_{2}$, rice plants develop pore spaces (aerenchyma) that allow $\mathrm{O}_{2}$ transport from air to the roots. Carrying capacity is determined by the rice genome and it may vary among cultivars. Plants that have higher capacity for formation of aerenchyma should theoretically carry more $\mathrm{O}_{2}$ to the roots. However, part of the $\mathrm{O}_{2}$ that reaches the roots is lost due to permeability of the roots and the $\mathrm{O}_{2}$ gradient created between the soil and roots. The $\mathrm{O}_{2}$ that is lost to the outside medium can react with chemically reduced elements present in the soil; one of them is iron, which reacts with oxygen and forms an iron plaque on the outer root surface. Therefore, evaluation of the iron plaque and of the formation of pore spaces on the root can serve as a parameter to differentiate rice cultivars in regard to the volume of $\mathrm{O}_{2}$ transported via aerenchyma. An experiment was thus carried out in a greenhouse with the aim of comparing aerenchyma and iron plaque formation in 13 rice cultivars grown in flooded soils to their formation under growing conditions similar to a normal field, without free oxygen. The results indicated significant differences in the volume of pore spaces in the roots among cultivars and along the root segment in each cultivar, indicating that under flooded conditions the genetic potential of the plant is crucial in induction of cell death and formation of aerenchyma in response to lack of $\mathrm{O}_{2}$. In addition, the amount of Fe accumulated on the root surface was different among genotypes and along the
\end{abstract}

(1) This work was supported by Instituto Rio Grandense do Arroz - IRGA. Received for publication on February 4, 2013 and approved on September 12, 2013.

(2) Doctoral in Soil Science, Universidade Federal do Rio Grande do Sul - UFRGS. Av. Bento Gonçalves, 9500. CEP 91501-970 Porto Alegre (RS), Brazil. Bolsista CAPES. E-mail: marquelrs@yahoo.com.br

(3) Post-Graduation student in Soil Science, UFRGS. Bolsista CAPES. E-mail: filipeselaucarlos@hotmail.com

(4) Researcher, IRGA. Av. Bonifácio Carvalho Bernardes, 1494. CEP 94930-030 Cachoeirinha (RS), Brazil. E-mail: humbertobohnen@uol.com.br, felipe.c.carmona@gmail.com

(5) Full Professor, Soil Science, UFRGS. CNPq fellowship. E-mail: ibanghi@ufrgs.br 
roots. Thus, we concluded that the rice genotypes exhibit different responses for aerenchyma formation, oxygen release by the roots and iron plaque formation, and that there is a direct relationship between porosity and the amount of iron oxidized on the root surface.

Index terms: anaerobiosis, Oryza sativa L., pore spaces.

\title{
RESUMO: OXIDAÇÃO DOFERRO NA SUPERFÍCIE DE RAÍZES ADVENTÍCIAS E SUA RELAÇÃO COM A FORMAÇÃO DE AERÊNQUIMA EM GENÓTIPOS DE ARROZ
}

\begin{abstract}
Com o estabelecimento da lâmina de água em lavouras de arroz irrigado, o $\mathrm{O}_{2}$ livre é consumido e o solo entra num processo de redução química mediado por microrganismos anaeróbios, alterando o ambiente onde a cultura se desenvolve. Para manter o crescimento sem $\mathrm{O}_{2}$, o arroz desenvolve o aerênquima, que permite o transporte de $\mathrm{O}_{2}$ do ar até as raízes. A capacidade de formar aerênquima é genética e pode variar entre cultivares; portanto, plantas com maior capacidade de formar aerênquima, teoricamente, transportam mais $\mathrm{O}_{2}$ para as raizes. Entretanto, parte do $\mathrm{O}_{2}$ que chega até as raizes é perdido para o meio externo, que reage com elementos quimicamente reduzidos no solo, entre eles o $\mathrm{Fe}^{2+}$, que se oxida e forma a chamada placa férrica na superfície da raiz. Assim, a determinação da placa férrica e da formação de espaços porosos na raiz pode servir como parâmetro para diferenciar cultivares de arroz quanto ao volume de $\mathrm{O}_{2}$ transportado via aerênquima. Dessa forma, foi conduzido um experimento em casa de vegetação, visando comparar a formação de aerênquima e da placa férrica em 13 cultivares de arroz em solo alagado, com condições semelhantes às normais de cultivo no campo, sem a presença de $\mathrm{O}_{2}$. Os resultados indicaram diferenças marcantes nos volumes de espaços porosos nas raizes, entre os cultivares e ao longo do segmento da raiz em cada cultivar, indicando que, nas condições de solo alagado, o potencial genético da planta é determinante na indução à morte celular e na formação de aerênquima, em resposta à falta de $\mathrm{O}_{2}$. Também, a quantidade de Fe acumulada na superfície das raízes foi diferente entre os genótipos e ao longo da raiz. Assim, concluiu-se que os genótipos de arroz apresentam resposta diferenciada quanto à formação de aerênquima, liberação de $\mathrm{O}_{2}$ pelas raizes e formação da placa férrica e que existe relação direta entre porosidade e quantidade de Fe oxidado na superfície das raizes.
\end{abstract}

Termos de indexação: anaerobiose, Oryza sativa L., espaços porosos.

\section{INTRODUCTION}

In wetland rice fields, establishment of the water layer modifies chemical and biological conditions, leading to consumption of free $\mathrm{O}_{2}$ and the formation of toxic products such as organic acids and high concentrations of chemically reduced iron $\left(\mathrm{Fe}^{2+}\right)$ and manganese $\left(\mathrm{Mn}^{2+}\right)$ (Kirk, 2004). Such changes require plants to develop mechanisms that allow them to carry $\mathrm{O}_{2}$ to the roots to maintain breathing and normal growth (Jackson \& Armstrong, 1999).

The most important adaptation is the formation of pore spaces within the root and shoot tissues, called aerenchyma (Jackson \& Armstrong, 1999; Evans, 2003; Kirk, 2004). Aerenchyma formation occurs in two ways. In the first, called constitutive or schizogenous, pore space results from separation and expansion of cells, creating intercellular spaces that are part of normal development of plants even at appropriate levels of $\mathrm{O}_{2}$ (Jeffree et al., 1986). The second type of aerenchyma, called lysigenous, is formed by the death of cells in the stem and roots through a biochemical process triggered by waterlogged soil conditions, especially the lack of $\mathrm{O}_{2}$ (Jackson \& Armstrong, 1999; Evans, 2003). The formation of lysigenous aerenchyma starts in the roots, mainly in adventitious roots, and extends to the base and the shoot (Thomson et al., 1990). This type of formation results in empty spaces in the cortex of the stem and roots, forming a continuum between the atmosphereshoots-roots (Evans, 2003; Kirk, 2004) and this makes the largest contribution to the $\mathrm{O}_{2}$ supply to rice roots and can represent more than $30 \%$ of total tissue volume (Luxmoore et al., 1970). Differences in the volume of pore spaces occur in different types of roots and even along the same root. For example, Armstrong (1971) observed aerenchyma volumes of $9 \%$ at the root tip and $45 \%$ in mature regions near the base of the rice plant.

The effectiveness of internal transport of $\mathrm{O}_{2}$ by diffusion or convection depends on the physical resistance caused by the tortuosity of the pores, on the distance traveled (Kirk, 2004), on the demand for $\mathrm{O}_{2}$ as a function of root tissue respiration rates, on soil loss and on microorganism consumption (Kludze et al., 1993; Hosono \& Nouchi. 1997; Kirk, 2004). 
These factors are determined by plant genetic potential, suggesting differences between species, and even among rice cultivars (Aulakh et al., 2000). In this case, plants with high genetic capacity for forming pore spaces can theoretically carry more oxygen to the roots, favoring their growth and, consequently, greater depth in the soil, which may be desirable due to a larger volume of soil exploited in the search for nutrients (Ponnamperuma, 1972). However, the $\mathrm{O}_{2}$ transported to the roots is partially lost to the soil, mainly because of the $\mathrm{O}_{2}$ gradient created between the reduced soil and the inside of the root. The intensity at which these losses occur is determined by root characteristics such as type, age, cell wall thickening, area and volume of pore spaces (Colmer, 2003). The amount of oxygen transported and released by rice roots can vary among cultivars due to variation in the volume of aerenchyma (Bedford et al., 1991), suggesting differences in the ability of forming a hypoxic or aerobic environment in the rhizosphere. This variation can influence the activity of aerobic microorganisms and the intensity of chemical and biological reactions in the rhizosphere (Colmer, 2003).

Oxygen release in the rhizosphere also enables oxidation of $\mathrm{Fe}^{2+}$ to $\mathrm{Fe}^{3+}$ in the form of amorphous iron oxyhydroxides and thereby results in its accumulation on the root surface and cells that form the epidermal layers (Tanaka \& Navasero, 1966), commonly called "iron plaque" (Chen et al., 1980). However, oxidation of $\mathrm{Fe}$ corresponds to only part of the oxygen released by the roots; it is necessary to consider consumption by microorganisms and other chemical reactions (Kirk, 2004). Since the reactions that occur in the rhizosphere are numerous, dynamic and fast, it is difficult to evaluate the total release of $\mathrm{O}_{2}$ in situ by the roots, as well as the intensity of the chemical reactions. Several studies involving measurement of $\mathrm{O}_{2}$ losses by roots have been developed in recent years. However, due to the ease with which $\mathrm{O}_{2}$ diffuses through organic matter and water, it is difficult to create and/or maintain an environment free of molecular $\mathrm{O}_{2}$ when working with a nutrient solution with rice. Some techniques which have been used for these studies, such as cultivation in an agar medium in containers permeable to $\mathrm{O}_{2}$, exclusion of $\mathrm{O}_{2}$ with $\mathrm{N}_{2}$, and reducing inorganic salts, among others, have not been effective in excluding $\mathrm{O}_{2}$ from the root environment, leading to conclusions that do not always express the real environment of a rice plant in flooded soil (Holzschuh et al., 2010).

Therefore, this study was conducted in order to compare rice genotypes with contrasting genetic bases in regard to their ability to form aerenchyma and to transport and release oxygen into the rhizosphere through the method of adventitious roots grown in an environment lacking free oxygen, as in flooded soil.

\section{MATERIALS AND METHODS}

The experiment was carried out at the Rice Research Station (Estação Experimental do Arroz EEA) of the Instituto Rio Grandense do Arroz (IRGA) (Cachoeirinha, RS, Brazil) from November 2008 to February 2009. The treatments compared the following rice genotypes, representing a broad genetic base: EPAGRI 108, EEA 406, BR-IRGA 409, IRGA 417, IRGA 420, IRGA 423, IRGA 424, IRGA 3073, Bluebelle, Orizica, Arize QM 1010, Avaxi and Formosa. The genotypes were initially cultivated in the field until the early flowering stage in a soil classified as a Typic Haplaquents (Streck et al., 2008) with clay content $=14 \%, \mathrm{pH}=6.6, \mathrm{SOM}$ (soil organic matter) $=1.8 \%$, $\mathrm{P}=33 \mathrm{mg} \mathrm{dm}{ }^{-3}, \mathrm{~K}=47 \mathrm{mg} \mathrm{dm}^{-3}, \mathrm{Al}=0.1 \mathrm{cmol}_{\mathrm{c}} \mathrm{dm}^{-3}$, $\mathrm{Ca}=1.7 \mathrm{cmol}_{\mathrm{c}} \mathrm{dm}^{-3}$ and $\mathrm{Mg}=1.2 \mathrm{cmol}_{\mathrm{c}} \mathrm{dm}^{-3}$. Determination of the development of new adventitious roots, root porosity and Fe plaque is described below, according to the method proposed by Holzschuh et al. (2010).

\section{Obtaining roots of rice plants in a hypoxia environment}

The study was carried out in a greenhouse with temperatures ranging from $20-30{ }^{\circ} \mathrm{C}$. A hypoxic condition was obtained by exploiting oxygen diffusion ability through the plastic vinyl material in contact with the soil in a chemical reduction process. For this purpose, vinyl bags with dimensions of $30 \times 40 \mathrm{~cm}$ and $0.1 \mathrm{~mm}$ thickness were used.

To develop new adventitious roots, $50 \mathrm{~L}$ capacity asbestos boxes were used. Each box received five vinyl bags, which were placed on a $5.0 \mathrm{~cm}$ soil layer at the bottom of the box, with a $10.0 \mathrm{~cm}$ distance between them. An internal spacer $(10 \mathrm{~mm}$ diameter electrical conductor) was placed in each bag in order to maintain an adequate space for root development without physical resistance. The boxes were filled with Typic Haplaquents (Streck et al., 2008) soil, leaving the bag opening at $10.0 \mathrm{~cm}$ above the soil surface. Each bag received $150 \mathrm{~mL}$ of nutrient solution with the following composition in mmol L-1: $3.0 \mathrm{~N}-\mathrm{NO}_{3}^{-}, 1.5 \mathrm{~N}^{-\mathrm{NH}_{4}}{ }^{+}$, $0.5 \mathrm{P}, 2.0 \mathrm{~K}, 1.5 \mathrm{Ca}, 1.0 \mathrm{Mg}, 0.023 \mathrm{~B}, 3.0 \mathrm{Cl}, 0.0047$ $\mathrm{Cu}, 0.18 \mathrm{Fe}, 0.047 \mathrm{Mn}, 0.00011 \mathrm{Mo}, 0.0015 \mathrm{Zn}$ and pH 5.5 (Silva \& Bohnen, 2001). The soil was flooded and maintained at a $5.0 \mathrm{~cm}$ water depth for two weeks, which is long enough for the soil to be chemically reduced.

Plants of the different genotypes initially grown in the field until the beginning of the flowering stage were removed whole from the soil and taken to the laboratory, where uniform and vigorous tillers were separated and all the roots were cut near the stem of each plant. The plants were thoroughly washed to avoid contamination with soil in the process of cultivation of adventitious roots. To reduce the transpiration rate, $1 / 3$ of the leaf blades were removed. These plants were placed in vinyl bags so that their 
root collars were at the height of the soil surface. Each bag received 12 plants of each genotype. After a period of seven days, with newly formed adventitious roots, plants were removed from the bags and immediately taken to the laboratory. The nutrient solution was regularly restored in the bags when the volume was reduced by evapotranspiration. Analysis for monitoring oxygen dissolved in the bags during root formation indicated a concentration of less than $0.1 \mathrm{mg} \mathrm{L}^{-1}$ near the root collar (lower limit of detection of the oximeter used), indicating the efficiency of the method in removing the $\mathrm{O}_{2}$ and bringing about a hypoxic environment.

\section{Iron plaque}

In the laboratory, seven roots of each genotype were cut in $7.0 \mathrm{~cm}$ segments as of the apex. The roots were fixed in an acrylic holder, placed in a glass box $(20 \times$ $10 \times 1.5 \mathrm{~cm})$ and flooded with ultra pure nitrogen $\left(\mathrm{N}_{2}\right)\left(<1 \mathrm{mg} \mathrm{L}^{-1} \mathrm{O}_{2}\right)$ in order to remove the free oxygen. The glass box was filled with soil solution of a previously flooded Albaqualf (Streck et al., 2008) soil with a history of Fe toxicity induction in susceptible cultivars and a stabilized reduction process, with $\mathrm{pH}=6.2$ and $80 \mathrm{mg} \mathrm{L}^{-1}$ of iron $\left(\mathrm{Fe}^{2+}\right)$. The soil solution was obtained by a system comprised of a $50 \mathrm{~L}$ asbestos box filled with an Albaqualf soil in an advanced stage of chemical reduction (Nava, 1997). The roots remained in the soil solution for a period of four hours so that the oxygen gradient formed between the inner root (aerenchyma) and the soil solution would promote the diffusion of molecular oxygen to the outside of the roots. The contact time was established from prior testing to keep the Fe concentration in the solution from falling to very low levels, which would impede diffusion of $\mathrm{Fe}$ along the roots. The release of oxygen by the root and the combination with $\mathrm{Fe}^{2+}$ results in the formation of oxidized Fe compounds with low crystallinity, forming the Fe plaque on the root surface. After $4 \mathrm{~h}$ in contact with the soil solution, the roots were washed and cut into $2.0 \mathrm{~cm}$ segments as of the apex, making up samples from each region of the root, which included the segments of $0-2,2-4$ and $4-6 \mathrm{~cm}$. The segments were individually photographed and analyzed with the software SIARCS v. 3.0 to calculate the surface area of the segment. Each segment received the addition of $1.0 \mathrm{~mL}$ of $0.5 \mathrm{~mol} \mathrm{~L}^{-1} \mathrm{HCl}$ and was kept at rest for $24 \mathrm{~h}$ to extract the Fe contained in the root, characterizing each replication, for a total of seven replications for each segment and genotype. The concentrations of dissolved $\mathrm{Fe}$ in the samples were determined by atomic absorption spectrophotometer (Nava \& Bohnen, 2002). From the digitized images, the surface area of the segment was calculated with the software SIARCS v. 3.0 which, together with the Fe concentration in the sample, allows calculation of the distribution of the chemical element in the segment.

\section{Root porosity}

From the same plants used for determination of Fe plaque, another group of roots was removed for determination of porosity. Of these, 30 roots were cut into segments of 0-2, 2-4 and 4-6 cm from the apex, forming three replicates with 10 roots for each segment and genotype. Each experimental unit consisted of a group containing 10 segments (replicate). Each group was carefully dried with tissue paper to remove excess water from the root surface and weighed. This determination composed the dry weight of the roots containing the empty spaces of the aerenchyma within. The segments were then placed in a plastic syringe $(60 \mathrm{~mL})$ containing $10 \mathrm{~mL}$ of water. The volume of the syringe was reduced to $10 \mathrm{~mL}$ and its inlet was sealed with a silicone. The plunger was pulled and locked to maintain a vacuum for 3 min to extract the air from the roots. After that, the plunger was released and maintained for another $3 \mathrm{~min}$, allowing entry of water into the vacuum created inside the roots. This cycle was repeated until all the segments were deposited at the bottom of the syringe, indicating that the pore space was completely filled with water. The roots were removed from the syringe and dried again on the outside with tissue paper and weighed. The fresh matter difference before and after the vacuum and water intake treatment in the root was assumed to correspond to root porosity, resulting in an estimate of the magnitude of aerenchyma formed in each segment along the root. This evaluation considers that the ratio of the volume of water at room temperature and the specific gravity is equal to 1 and, in this case, can be used as an estimate of the volume of the pore spaces in the root.

The test was conducted in a completely randomized block statistical design with three replications. The results of the weights of the root groups in evaluating the porosity and the Fe content in each segment was considered simple variables with respective replications and were subjected to analysis of variance $(p<0.05)$ and, when significant, comparison of mean values of the treatments by the LSD test $(p<0.05)$ was performed. Furthermore, the results of porosity and total iron in each segment were correlated, and correlation coefficients were shown for each genotype.

\section{RESULTS AND DISCUSSION}

The volume of pore spaces varied $(p<0.05)$ among genotypes for each of the three segments evaluated and also among segments (Figure 1). For all genotypes, porosity increased from the apex to the root base, as the root became more mature (Figure 1). The amplitude of these variations within each segment was from 2 to 16, 22 to 56 and 45 to $89 \%$ for 0-2, 2-4 and $4-6 \mathrm{~cm}$, respectively (Figure 1), indicating that the genotypes with a different genetic base reacted differently to $\mathrm{O}_{2}$ limitation. Significant variations 
among rice genotypes and among root regions were also reported by Armstrong (1971) and Armstrong \& Armstrong (2005).

In descending order, the genotypes Bluebelle, EEA 406, Avaxi, IRGA 420, Arize QM 1010 and EPAGRI 108 developed larger diameter roots than the other genotypes (Figure 2). According to Armstrong (1979) and Sorrell et al. (2000), the thickness of the stem and root structure is related to the volume of aerenchyma formed and, hence, to the volume of $\mathrm{O}_{2}$ transported by these structures. However, the results of this study did not show this tendency, and indicated that the genotypes with the highest porosity were Orizica, EPAGRI 108 and Formosa (Figure 3). When

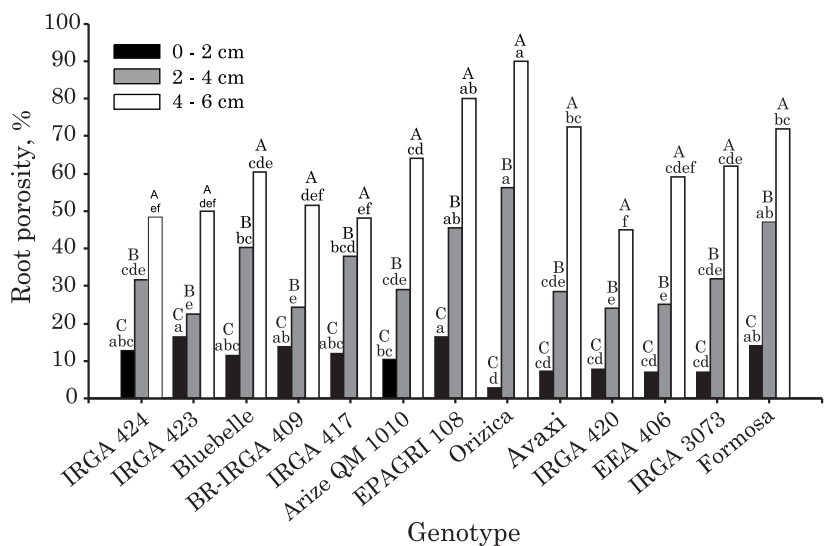

Figure 1. Porosity in three segments of adventitious roots of rice genotypes obtained in hypoxia. Lowercase letters compare genotypes for each segment and uppercase letters compare segments within each genotype by the LSD test $(\mathrm{p}<0.05)$.

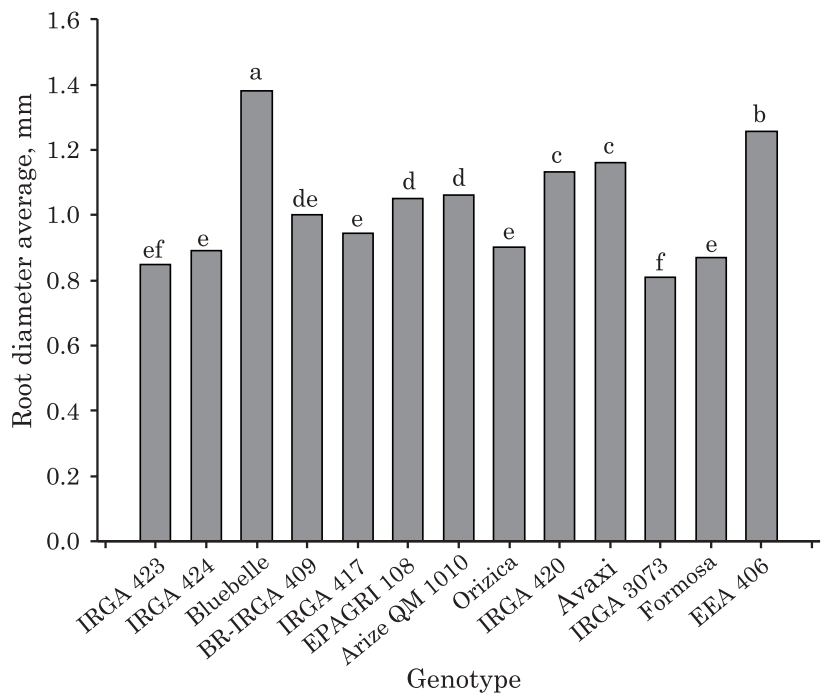

Figure 2. Average diameter in three segments of adventitious roots of rice genotypes produced under conditions of hypoxia. Lowercase letters compare genotypes by the LSD test $(p<0.05)$. all of the genotypes are analyzed, it is possible to observe that there was no clear relationship between diameter and porosity (Figures 2 and 3), which may be related to the composition of the internal structure of the roots and epidermal cells so as to maintain sufficient levels of $\mathrm{O}_{2}$ within the root to maintain respiration. An important drain of $\mathrm{O}_{2}$ in the roots is associated with release to outside the roots due to the lack of $\mathrm{O}_{2}$ in the flooded soil. In this case, a way of assessing the permeability of the roots to $\mathrm{O}_{2}$ is through determination of the iron deposited on the surface of the roots due to oxidation of $\mathrm{Fe}^{2+}$ to $\mathrm{Fe}^{3+}$.

The amount of Fe accumulated on the root surface (iron plaque) was different $(\mathrm{p}<0.05)$ among the genotypes and the segments (Figure 4). In general, the amount of oxidized iron increased from the apex $(0-2 \mathrm{~cm})$ to the most mature region of the root $(2-4$ and 4-6 cm), in accordance with the behavior of formation of aerenchyma for all the genotypes (Figure 1). This indicates that there is a positive relationship between porosity, oxidized Fe and the oxygen transported through the aerenchyma.

The correlation of porosity with Fe accumulation in the different segments evaluated indicates that although the increase in porosity is positively related to the amount of oxidized Fe, this relationship is not proportional among genotypes, as can be seen in the slope of the straight lines (Figure 5a,b). This behavior becomes more apparent when the formation of average porosity and the cumulative sum of $\mathrm{Fe}$ along the segments (Figures 1 and 6, respectively) is considered. It may be observed that some genotypes that have the highest average porosities, like EPAGRI 108, Orizica and Formosa, did not necessarily have the highest amounts of oxidized $\mathrm{Fe}$ along the roots. Therefore, it is not possible to affirm that pore volume per se is the determining factor of the amount of oxygen

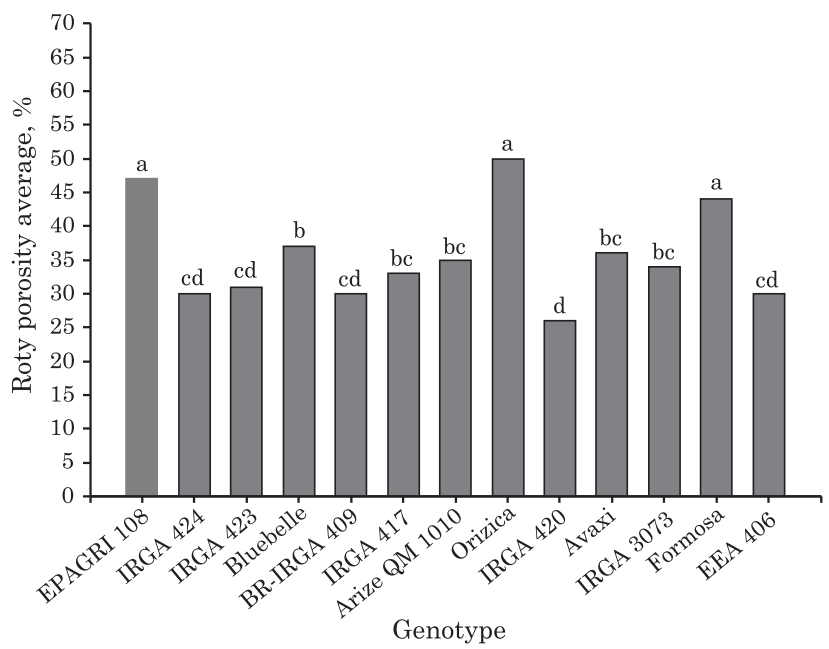

Figure 3. Average relative porosity in three segments of adventitious roots of rice genotypes produced under conditions of hypoxia. Lowercase letters compare genotypes by the LSD test $(p<0.05)$. 
released to the rhizosphere. This fact is more evident for the genotype Orizica, which has the highest porosity and smallest amount of oxidized iron per unit of root area, as well as IRGA 420, which had less root

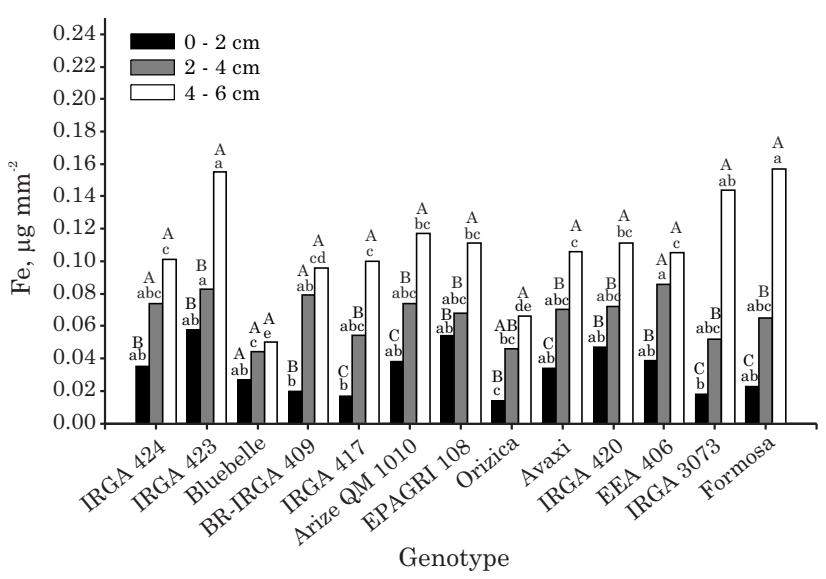

Figure 4. Iron distribution in three segments of adventitious roots of rice genotypes obtained under hypoxia after exposure to a solution of an Albaqualf soil with $\mathrm{pH}=6.0$ and $80 \mathrm{mg} \mathrm{L}^{-1}$ of Fe. Lowercase letters compare genotypes for each segment and uppercase letters compare segments within each genotype by the LSD test $(p<0.05)$.

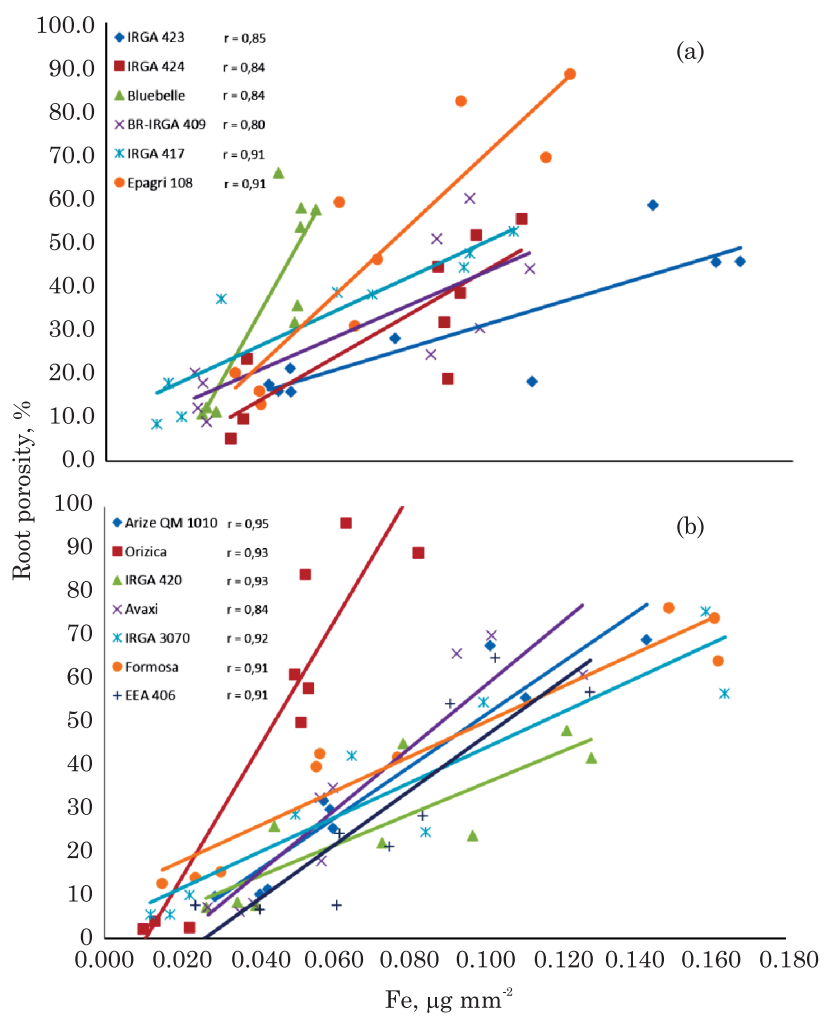

Figure 5. Correlation between porosity and total iron in segments of adventitious roots of rice genotypes $(a, b)$ obtained under hypoxia after four hours of exposure to an Albaqualf soil solution with $\mathrm{pH}=6.0$ and $80 \mathrm{mg} \mathrm{L}^{-1} \mathrm{of} \mathrm{Fe}$. porosity than Orizica but higher Fe plaque formation (Figures 1 and 6, respectively). Likewise, genotypes Arize, QM 1010, IRGA 423, Avaxi and EEA 406, which showed intermediate average porosities, had the highest values of total Fe (Figures 1 and 6, respectively). This type of behavior occurs because each genotype shows variations in root permeability, both for oxygen and for other gases, water, nutrients and toxic compounds, which alters the dynamics of exchanges between the inner root and the external environment (Colmer, 2003; Kirk, 2004; Kotula \& Steudle, 2009).

Accordingly, other plant adaptations to oxygen losses may be listed in addition to aerenchyma formation. The formation of physical barriers, for example, reduces or prevents the outflow of oxygen in the outermost layers of the root cells, allowing the oxygen supply to be maintained at adequate levels within the root tissue, especially at the apex (Armstrong, 1979; Colmer, 2003; Kotula et al., 2009). Formation of these barriers is determined by characteristics of the cell walls that make up the epidermis and exodermis of roots, such as thickness and chemical composition (Colmer, 2003). The accumulation of lignin and suberin polymers around the cells of the endodermis and exodermis confers resistance to radial oxygen loss, becoming a determining factor in the permeability of the roots (Armstrong et al., 2000; Armstrong \& Armstrong, 2005)

In rice, the degree of suberization and lignification of cell walls increases significantly as the root becomes mature and this is indicated as the main factor for reducing oxygen loss from the root (Armstrong \&

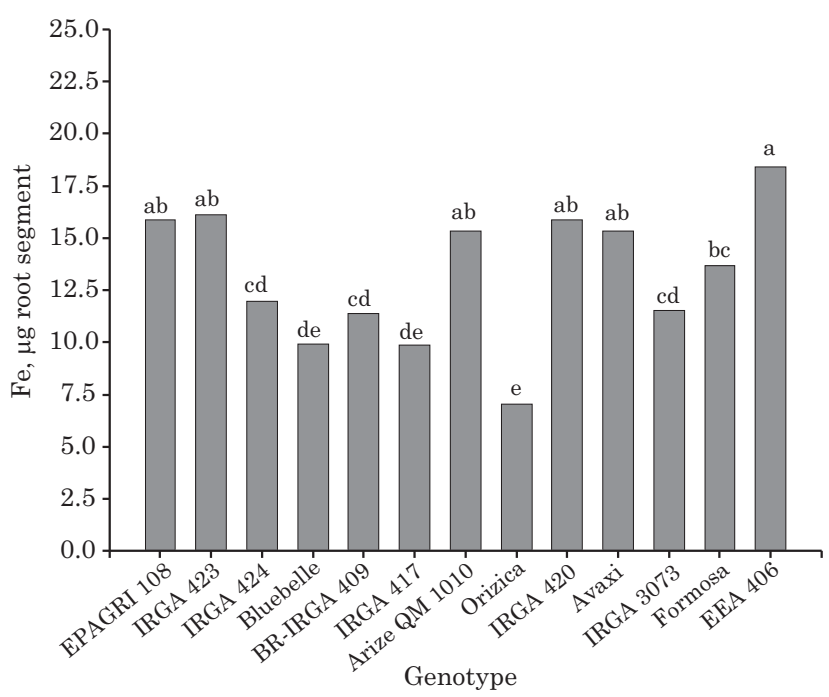

Figure 6. Total iron (sum of three segments) on the surface of adventitious roots of rice genotypes after exposure to a solution of an Albaqualf soil with $\mathrm{pH}=6.0$ and $80 \mathrm{mg} \mathrm{L}^{-1}$ of Fe. Lowercase letters compare genotypes by the LSD test $(p<0.05)$. 
Armstrong, 2005; Kotula \& Steudle, 2009; Kotula et al., 2009). On the other hand, considering that in the region closest to the root apex the formation of these barriers is less, due to this region being in full growth (Kotula \& Steudle, 2009; Armstrong \& Armstrong, 2005; Kotula et al., 2009), the cumulative a mount of Fe is also small (Figure 4). This is because porosity in this region is also lower (Figure 1) and, moreover, it is in this region that the cell respiration rate is more intense, thus consuming part of the oxygen that reaches this location (Kirk, 2004). On the other hand, Armstrong \& Armstrong (2005) observed that radial oxygen loss was higher in the zone near the apex of adventitious rice roots grown under low $\mathrm{O}_{2}$ availability compared to plants grown in an aerated solution.

Although the loss of oxygen to the environment external to the root looks like a negative process, by reducing the amount of oxygen available for cell respiration, and the formation of barriers being agents for reducing these losses, attention should also be given to the fact that oxygen release has important functions on root metabolism. Among the main functions is the reduction of exposure to $\mathrm{Fe}^{2+}, \mathrm{Mn}^{2+}, \mathrm{H}_{2} \mathrm{~S}, \mathrm{~S}^{2-}$, HS- and organic acids (Armstrong, 1971; Begg et al., 1994; Revsbech et al., 1999). However, the barriers that reduce the permeability of the root to oxygen also interfere with the entry of water and nutrients in the root (Armstrong, 1979; Kirk, 2003). According to Kirk (2004), the most mature roots have less importance in the process of uptake of water and nutrients compared to the apex region, mainly due to permeability. The greatest contribution of nutrients and water would be associated with the development of lateral roots, due to their greater number, increased specific surface area, and also because they are directly connected with the root xylem.

\section{CONCLUSIONS}

1. Rice genotypes with a contrasting genetic basis respond differently in regard to formation of aerenchyma and release of oxygen by the roots.

2 . The porosity of adventitious roots of rice genotypes is directly related to the formation of iron plaque, but with different magnitudes for each irrigated rice genotype.

\section{LITERATURE CITED}

ARMSTRONG, W. Aeration in higher plants. Adv. Bot. Res., 7:225-332, 1979 .

ARMSTRONG, W. Radial oxygen losses from intact rice roots as affected by distance from the apex, respiration, and waterlogging. Physiol. Plant., 25:192-197, 1971.
ARMSTRONG, J. \& ARMSTRONG, W. Rice: Sulfide-induced barriers to root radial oxygen loss, $\mathrm{Fe}^{2+}$ and water uptake, and lateral root emergence. Ann. Bot., 96:625-638, 2005.

ARMSTRONG, W.; COUSINS, D.; ARMSTRONG, J.; TURNER, D.W. \& BECKETT, P.M. Oxygen distribution in wetland plant roots and permeability barriers to gas-exchange with the rhizosphere: a microelectrode and modeling study with Phragmites australis. Ann. Bot., 86:687-703, 2000.

AULAKH, M.S. Pattern and amount of aerenchyma relate to variable methane transport capacity of different rice cultivars. Plant Biol., 2:182-194, 2000.

BEDFORD, B.L.; BOULDIN, D.R. \& BELIVEAU, B.D. Net oxygen and carbon dioxide balances in solutions bathing roots of wetland plants. J. Ecol., 79:943-959, 1991.

BEGG, C.B.M.; KIRK, G.J.D.; MACKENZIE, A.F. \& NEUE, H.U. Root-induced iron oxidation and $\mathrm{pH}$ changes in the lowland rice rhizosphere. New Phytol., 128:469-477, 1994.

CHEN, C.C.; DIXON, J.B. \& TURNER, F.T. Iron coatings on rice roots: Morphology and models of development. Soil Sci. Soc. Am. J., 44:1113-1119, 1980.

COLMER, T.D. Long-distance transport of gases in plants: A perspective on internal aeration and radial oxygen loss from roots. Plant Cell. Environ., 26:17-36, 2003.

EVANS, D.E. Aerenchyma formation. New Phytol., 161:3549, 2003.

HOLZSCHUH, M.J.; BOHNEN, H. \& ANGHINONI, I. Avaliação da porosidade e placa férrica de raízes de arroz cultivados em hipoxia. R. Bras. Ci. Solo, 84:1763-1769, 2010.

HOSONO, T. \& NOUCHI, I. The dependence of methane transport in rice plants on the root zone temperature. Plant Soil, 191:233-240, 1997.

JEFFREE, C.E.; DALE, J.E. \& FRY, S.C. The genesis of intercellular spaces in developing leaves of Phaseolus vulgaris L.. Protoplasma, 132:90-98, 1986.

JACKSON, M. \& ARMSTRONG, W. Formation of aerenchyma and the processes of plant ventilation in relation to soil flooding and submergence. Plant Biol., 1:274-287, 1999.

KIRK, G.J.D. The biogeochemistry of submerged soils. Chichester, Wiley, 2004. 304p.

KIRK, G.J.D. Rice roots properties for internal aeration and efficient nutrient acquisition in submerged soil. New Phytol., 159:185-194, 2003.

KLUDZE, H.K.; DELAUNE, R.D. \& PATRICK Jr., W.H. Aerenchyma formation and methane and oxygen exchange in rice. Soil Sci. Soc. Am. J., 57:386-391, 1993.

KOTULA, L. \& STEUDLE, E. Measurements of oxygen permeability coefficient of rice (Oryza sativa L.) roots using a new perfusion technique. J. Exp. Bot., 60:567$580,2009$.

KOTULA, L.Z.; RANATHUNGE, K.; SCHREIBER, L. \& STEUDLE, E. Functional and chemical comparison of apoplastic barriers to radial oxygen loss in roots of rice (Oryza sativa L.) grown in aerated or deoxygenated solution. J. Exp. Bot., 60:2155-2167, 2009 
LUXMOORE, R.J.; STOLZY, L. \& LETEY, J. Oxygen diffusion in the soil plant system. Agron. J., 62:317-322, 1970.

NAVA, G. Oxidação do ferro em raízes de duas cultivares de arroz em solução de solo inundado. Porto Alegre, Universidade Federal do Rio Grande do Sul, 1997. 83p. (Dissertação de Mestrado)

NAVA, G. \& BOHNEN, H. Oxidação de ferro de dois cultivares de arroz em solução de solo inundado. R. Bras. Ci. Solo, 26:325-332, 2002.

PONNAMPERUMA, F.N. The chemistry of submerged soils. Adv. Agron., 24:29-96, 1972.

REVSBECH, N.P.; PEDERSEN, O.; REICHARDT, W. \& BRIONES, A. Microsensor analysis of oxygen and $\mathrm{pH}$ in the rice rhizosphere under field and laboratory conditions. Biol. Fert. Soils, 29:379-385, 1999.
SILVA, L.S. \& BOHNEN, H. Rendimento e acúmulo de nutrientes pelo arroz em solução nutritiva com e sem adição de silício. R. Bras. Ci. Solo, 25:771-777, 2001.

SORRELL, B.K.; MENDELSSOHN, I.A.; MCKEE, K.L. \& WOODS, R.A. Ecophysiology of wetland plant roots: A modelling comparison of aeration in relation to species distribution. Ann. Bot., 86:675-685, 2000.

STRECK, E.D.; KAMPF, N.; DALMOLIN, R.S.D.; KLAMT, E.; NASCIMENTO, P.C.; SCHNEIDER, P.; GIASSON, E. \& PINTO, L.F.S. Solos do Rio Grande do Sul. Porto Alegre, EMATER/RS-ASCAR, 2008. 222p.

TANAKA, A. \& NAVASERO, S.A. Growth of the rice plant on acid sulfate soils. Soil Sci. Plant Nutr., 12:107-114, 1966.

THOMSON, C.J.; ARMSTRONG, W.; WATERS, I. \& GREENWAY, H. Aerenchyma formation and associated oxygen movement in seminal and nodal roots of wheat. Plant Cell. Environ., 13:395-403, 1990. 